\title{
Significant contributing causes of cancer deaths among Hispanics in Colorado, USA, 1983-1992
}

\author{
Causas que contribuem para óbitos por câncer \\ em latinos no Colorado, EUA, 1983-92
}

Kimberley Sweitzer 1

Lorann Stallones 1

\footnotetext{
1 Colorado State University, Department of Environmental Health. Fort Collins, Colorado 80523 U.S.A
}

A bstract Cancer deaths in the state of Colorado, U.S.A., total ed 53,921 between 1983 and 1992. Death certificates for this period were used to evaluate Hispanic cancer deaths by contributing causes of death and primary occupation of the decedent. The relative risks for diabetes and liver disease as contributing causes of death were significantly higher among Hispanics when compared to non-Hispanics who had also died of cancer (RR for diabetes $=1.90 ; 95 \%$ C.I.$(1.64,2.19)$ and RR for liver disease $=1.44 ; 95 \%$ C.I. $(1.23,1.68)$ ). Hispani cs who had di ed of cancer were significantly less li kely to have drug abuse as a contributing cause of death when compared to nonHispanics (RR for drug abuse =0.69; 95\% C.I . (0.52,0.91)). Laborers, service workers, and clerical workers who were Hispanic,were si gni ficantly more likely to die of cancer with ei ther diabetes or liver disease as a contributing cause of death than were non-Hispanics in the same occupational category $(p<0.05)$. Chronic diseases, such as diabetes and liver disease, may be reducing the survivability of cancer among Hispanics.

Key words Neoplasms; Cause of Death; Differential Mortality; Hispanic Americans

Resumo Entre 1983 e 1997, ocorreram 53.921 óbi tos por câncer no Estado do Col orado, EUA. Os atestados de óbi to para este período foram utilizados para avaliar as causas que contribuíram para a mortee a ocupação principal dosóbi tos por câncer ocorridos em latinos neste período. Os ri scos relativos para diabetes e doença hepáti ca como causas associadas ao óbi to foram significativamente mai ores em latinos, comparativamente com não latinos que também faleceram com câncer (diabetes $R R=1,90$; I.C. 95\% 1,64-2,19; doença hepática RR =1,44; I.C. 95\% 1,231,68). O consumo de drogas como causa associada à morte entre latinos que faleceram por câncer aparentou ser signifi cati vamente menor que em não lati nos ( $R R=0,69$; I.C. 95\% 0,52-0,91). Operários, servidores públi cos e trabalhadores de escritório de origem latina ten deram a apresentar diabetes e doença hepática como causas associadas à morte por câncer em mai or freqüência, estati sti camente si gn ificativa, que não lati nos nos mesmos ramos de atividade $(p<0,05)$. Doenças crônicas, como diabetes e doença hepática, podem estar reduzindo a sobrevida por câncer em latinos.

Palavras-chave Neoplasias; Causa da Morte; Mortalidade Diferencial; Hispano-Americanos 
Introduction

Cancer data for Colorado Hispanics reveal an interesting paradox (Karp et al., 1991; Finch et al., 1997). Although the overall cancer incidence rate for Hispanics is lower than that for Anglos (Table 1), Hispanics have fewer cancer survivors after five years (Table 2). Survival rate is lower for Hispanics for all stages of initial cancer diagnosis (Table 2). The incidence-tomortality rate ratios for Colorado Hispanics in 1995 were approximately equal to those of Anglos (Table 3). However, historically, these ratios have been somewhat lower (Table 3).

Some cancers have shown strikingly increased rates among Colorado Hispanics compared to their Anglo counterparts (Table 4). Among these cancers is cervical cancer, which has almost twice the incidence rate among Colorado Hispanic women compared to Anglo women (Table 4). Cancers of the stomach, liver, gallbladder, larynx, and kidney have elevated incidence rates among Hispanics of both sexes (Table 4).

The objective of this research was to look at complicating medical factors which contributed to the cancer deaths of Colorado Hispanics. The hypothesis was that some chronic medical conditions may be reducing the fiveyear survival rate for Hispanics who have been diagnosed with cancer.

\section{Methodology}

Colorado death certificate data for the years 1983 through 1992 were obtained from the Health Statistics Section of the Colorado Department of Public Health and the Environment. Residents and nonresidents of Colorado who had died in the state during the ten-year period were included in the data set. To ensure compl ete resident data, an interstate exchange of death certificate information has been utilized by the state of Colorado. Therefore the data set also included Colorado residents who died in other States during the ten-year period (Colorado Department of Health, 1990).

The entire data set for the ten-year period was evaluated for cancer as an underlying or attributable cause of death, using the International Classification of Diseases (U.S. Department of Heath and Human Services, 1991) codes 1400-2399. The underlying cause of death was defined as the disease or injury that initiated the events leading directly to death (Colorado Department of Health, 1990). An attributable cause of death was defined as all those dis-
Table 1

*All cancer sites incidence rates per 100,000

Colorado residents in 1995 by Hispanic ethnicity.

\begin{tabular}{lcc}
\hline Ethnic group & Males & Females \\
\hline Anglo & 436.0 & 339.0 \\
Hispanic & 369.0 & 276.0
\end{tabular}

* Cancer in Colorado Colorado Department of Health 1997.

Table 2

*All cancers 5-year relative survival rates in Colorado 1984-1988 by stage at diagnosis and ethnicity.

\begin{tabular}{lcc}
\hline Stage & Anglos & Hispanics \\
\hline All stages & $53 \%$ & $44 \%$ \\
Localized & $85 \%$ & $75 \%$ \\
Regional & $57 \%$ & $51 \%$ \\
Distant & $15 \%$ & $13 \%$
\end{tabular}

* Cancer in Colorado Colorado Department of Health 1991.

Table 3

*Incidence-to-mortality rate ratios in Colorado by ethnicity.

\begin{tabular}{lcc}
\hline Ethnicity/gender & 1991-1993 & 1995 \\
\hline Anglo males & 2.8 & 2.5 \\
Hispanic males & 2.6 & 2.5 \\
Anglo females & 2.6 & 2.7 \\
Hispanic females & 2.5 & 2.7
\end{tabular}

* Cancer in Colorado Colorado Department of Health 1997. Rates are per 100,000 Colorado residents.

eases, morbid conditions, or injuries that either resulted in or contributed to the death (Colorado Department of Heal th, 1990).

For deaths with cancer as an underlying or attributable cause, all codes for additional causes were tabulated. There were a maximum of el even codes per death certificate describing the medical diagnosis and environmental cause of the death. Selected attributable causes of death which were of interest included: alcoholism (codes 3030-3039); diabetes (codes 2500-2509); heart disease (codes 4010-4299); drug abuse (codes 3050-3059); liver disease (codes 5700-5739); and injury (codes 80009999). More than one cause of death was listed 
Selected cancer sites with higher cancer incidence rates among Hispanic population in the State of Colorado, U.S.A., 1991-1993.

\begin{tabular}{|c|c|c|}
\hline Cancer site & Anglos & Hispanics \\
\hline \multicolumn{3}{|l|}{ Male } \\
\hline Colon and rectum & 42.3 & 58.8 \\
\hline Stomach & 8.1 & 14.6 \\
\hline Liver & 2.6 & 5.3 \\
\hline Gallbladder & 0.5 & 2.4 \\
\hline Pancreas & 10.1 & 12.4 \\
\hline Kidney & 11.9 & 17.2 \\
\hline Larynx & 5.6 & 6.5 \\
\hline \multicolumn{3}{|l|}{ Female } \\
\hline Cervix & 7.4 & 14.0 \\
\hline Stomach & 3.5 & 8.3 \\
\hline Liver & 1.6 & 3.2 \\
\hline Gallbladder & 1.0 & 2.7 \\
\hline Larynx & 1.4 & 2.1 \\
\hline Kidney & 6.6 & 8.7 \\
\hline Thyroid & 7.6 & 10.8 \\
\hline
\end{tabular}

* Cancer in Colorado, Colorado Department of Health, 1997. Rates per 100,000 Colorado residents.

on approximately $65 \%$ of all death certificates during this period.

Instructions on the State of Colorado Certificate of Death for line 10a regarding occupation are as follows: “Decedent's Usual Occupati on - give kind of work done during most of working life- do not use retired" (Colorado Department of Health, 1990:275). This information was available for the entire ten-year period. Blue collar worker categories were the occupational groups of interest. The following occupational category codes were used: service workers were identified using the occupational codes 433 to 469; laborers had occupational codes 863 to 889; and codes 303 to 389 defined clerical workers (Colorado Department of Health, 1989). These occupational categories are the 1980 Standard Occupational Classification code equivalents (Colorado Department of Health, 1989).

Hispanic origin was a variable included in the death certificate data. Ethnic origins included in the Hispanic category were: Mexican; Puerto Rican; Cuban; Central and South American; and other and unknown Spanish.

The data set was stratified and tabulated using Statgraphics Plus version 7 (Manugistics, 1995). Two-by-two tables were analyzed for rel-
Table 5

Relative risk for Hispanics of cancer death, complicated by selected diseases and hazardous exposures, State of Colorado, U.S.A., 1983-1992.

\begin{tabular}{|c|c|c|c|c|}
\hline $\begin{array}{l}\text { Complicating diseases } \\
\text { for cancer deaths }\end{array}$ & Hispanic & Non-Hispanic & $\mathrm{RR}$ & $95 \%-\mathrm{Cl}$ \\
\hline \multicolumn{5}{|l|}{ Diabetes } \\
\hline Present & 169 & 1,357 & 1.90 & $1.64-2.19$ \\
\hline Absent & 3,034 & 48,905 & & \\
\hline \multicolumn{5}{|l|}{ Heart disease } \\
\hline Present & 731 & 12,150 & 0.93 & $0.86-1.01$ \\
\hline Absent & 2,472 & 38,112 & & \\
\hline \multicolumn{5}{|l|}{ Alcoholism } \\
\hline Present & 12 & 151 & 1.21 & $0.66-2.31$ \\
\hline Absent & 3,191 & 50,111 & & \\
\hline \multicolumn{5}{|l|}{ Drug abuse } \\
\hline Present & 50 & 1,152 & 0.69 & $0.52-0.91$ \\
\hline Absent & 3,153 & 49,110 & & \\
\hline \multicolumn{5}{|l|}{ Liver disease } \\
\hline Present & 148 & 1,594 & 1.44 & $1.23-1.68$ \\
\hline Absent & 3,055 & 48,668 & & \\
\hline \multicolumn{5}{|l|}{ Injury } \\
\hline Present & 101 & 1,582 & 1.00 & $0.83-1.21$ \\
\hline Absent & 3,102 & 48,680 & & \\
\hline
\end{tabular}

ative risk estimates and $95 \%$ confidence intervals using Epi Info version 5 (Centers for Disease Control, 1991).

\section{Results}

Cancer deaths in Colorado between 1983 and 1992 totaled 53,921. Of these deaths, 3,203 had Hispanic origin designated on the death certificate. The overall Relative Risk (RR) of death from cancer for Hispanics compared to nonHispanics among all causes of death was 0.82 . The 95 percent confidence interval (95\% C.I.) for this risk was 0.80 to 0.85 .

Hispanics with cancer and diabetes listed as causes of death totaled 169 (Table 6). Non$\mathrm{Hispanics}$ with both diabetes and cancer listed as causes of death totaled 1,357. The RR for Hispanics having both causes of death, when compared to non-Hispanics who also died of both causes, was $1.90(1.64,2.19)$ as shown in Table 6.

Neither heart disease or alcoholism was found to be a significant contributing cause of death for Hispanic cancer patients (Table 5). Drug abuse, as a complicating cause of death among Colorado Hispanic cancer victims, was 
Table 6

Relative risk* for Hispanics of cancer death, complicated by selected diseases and hazardous exposures, by occupational groups in the state of Colorado, U.S.A., 1983-1992.

\begin{tabular}{lll}
\hline Diseases & RR* & $95 \% \mathrm{Cl}$ \\
\hline $\begin{array}{l}\text { Liver disease } \\
\text { Clerical workers }\end{array}$ & 2.15 & $1.07-4.32$ \\
$\quad$ Laborers & 1.70 & $1.19-2.41$ \\
$\quad$ Service workers & 1.73 & $1.01-2.94$ \\
Diabetes & & \\
$\quad$ Clerical workers & 2.47 & $1.18-5.16$ \\
$\quad$ Service workers & 1.84 & $1.14-2.96$
\end{tabular}

* Compared to non-Hispanic cancer deaths among those in the same occupational group.

significantly reduced in risk compared to nonHispanics (Table 5). Liver disease had a RR of 1.44 and was a significant contributing cause of death for Hispanics who had died of cancer (Table 5). Injury was not a significantly different risk factor for Hispanics who had died of cancer, compared to non-Hispanics (Table 5).

When selected blue-collar occupational categories were evaluated by cancer death and Hispanic origin, the aforementioned attributing causes of death emerged as significant factors. For Hispanic laborers and service and clerical workers who had died of cancer, the RR of liver disease as a complicating factor was significant when compared to non-Hispanics who had also died of cancer and had the same occupation (Table 6). When other job categories were evaluated by Hispanic ethnicity and cancer death, liver disease was not a significant factor. Many of the 20 occupational categories that were evaluated by Hispanic ethnicity and cancer death also had diabetes as a significant risk factor. Included in these occupational categories were clerical and service workers (Table 6).

\section{Discussion}

The explanation for Colorado Hispanics having both fewer cancers and reduced cancer survival is likely an interaction of many factors. This research indicates that diabetes and liver disease significantly contribute to cancer deaths in Hispanics.

Blue collar workers were of special interest because research has shown that within each ethnic segment in the United States (U.S.) those individuals are at increased risk of death (Sorlie et al., 1995). A number of authors have reported significantly increased rates of diabetes among Hispanic residents in the U.S. (Flegel et al., 1991; Samet et al., 1988; Baxter et al., 1993). Given these two situations, it was interesting to find that diabetes was not a significant risk for Hispanic laborers who had died of cancer, yet was a significant risk for many of the white collar categories. Increased rates of chronic liver disease among U.S. male Hispanics has been reported (Polednak, 1995), but is less studied than diabetes in Hispanics. It is therefore an important result that chronic liver disease was a significant risk factor for Hispanic blue collar workers who had died of cancer (Table 6). This is made more interesting by the finding that only the selected blue collar categories had chronic liver disease as a significant risk factor. Because the Hispanic cancer deaths were compared to non-Hispanics who had also died of cancer and were in the same occupational categories, this finding suggests that there may be some interaction between a lower socioeconomic status (SES) and Hispanic ethnicity that results in chronic liver disease and cancer.

\section{Conclusions}

Colorado Hispanics are less likely to survive cancer than are their non-Hispanic counterparts. Diabetes and liver disease may be contributing to this fact. Hispanics who are blue collar workers are at greatest risk of a cancer death complicated by liver disease. 


\section{Acknowledgments}

The authors would like to thank the Colorado Department of Health for providing the data necessary to do this research and the National Cancer Institute for funding the project.

\section{References}

BAXTER, J.; HAMMAN, R. F.; LOPEZ, T. K.; MARSHALL, J. A.; HOAG, S. \& SWENSON, C. J., 1993. Excess incidence of known non-insulin-dependent mellitus (NIDDM) in Hispanics in New Mexico. Ethnicity and Disease, 3:11-21.

CENTERS FOR DISEASE CONTROL AND PREVENTION/ WORLD HEALTH ORGANIZATION, 1994. Epi - Info 6, Version 6.02. Atlanta: Centers for Disease Control \& Prevention/ World Health Organization.

COLORADO DEPARTMENT OF HEALTH, 1989. Colorado Death Certificate Master. Denver: Colorado Department of Health.

COLORADO DEPARTMENT OF HEALTH, 1990. Colorado Vital Statistics. Denver: Colorado Department of Health.

FLEGEL, K. M.; EZZATI, T. M.; HARRIS, M. I.; HAYNES, S. G.; JUAREZ, R. Z.; KNOWLER, W. C.; PEREZ-STABLE, E. J. \& STERN, M. P., 1991. Prevalence of diabetes in Mexican Americans, Cubans, and Puerto Ricans from the Hispanic Health and Nutrition Examination Survey, 1982-1984. Diabetes Care, 14:628-638.

FINCH, J. L.; BERG, J. W.; BOTT, R. \& FERG, H., 1997. Cancer in Colorado 1991-1995; Incidence and Mortality. Denver: Colorado Central Cancer Registry, Colorado Department of Health.
KARP, S.; FINCH, J. L.; BOTT, R. \& YOUNG, W. F., 1991. Cancer in Colorado 1979 to 1988. Denver: Colorado Department of Health.

M ANUGISTICS INC., 1995. Statgraphics Plus Reference Manual, Version 7. Cambridge: Bitstream Inc.

POLEDNAK, P. P., 1995. Estimating mortality in the Hispanic population of Connecticut, 1990 to 1991. American Journal of Public Health, 85:9981004.

SAMET, J. M.; COULTAS, D. B.; HOWARD, C. A.; SKIPPER, B. J. \& HANIS, C. L., 1988. Diabetes, gallbladder disease, obesity, and hypertension among Hispanics in New Mexico. American Journal of Epidemiology, 128:1302-1311.

SORLIE, P. D.; BACKLUND, E \& KELLER, J. B., 1995. U.S. mortality by economic, demographic, and social characteristics: the national longitudinal mortality study. American Journal of Public Health, 85:949-956.

U. S. DEPARTMENT OF HEALTH AND HUMAN SERVICES, 1991. International Classification of Diseases. Washington: U. S. Department of Health and Human Services. 